\title{
A STUDY ON TREND AND GROWTH OF GRAPE IN TAMIL NADU
}

\section{Dr. R. ANGAMUTHU}

Assistant Professor, PG \& Research Department of Commerce, (Deputed from Annamalai University), Government Arts College, Tiruvannamalai - 606603

\section{Abstract}

In this paper analysis Area, Production and Productivity of Grape in Tamil Nadu during the year from 2008-09 to 2017-18.Grape cultivation is believed to have originated in Armenia near the Caspian Sea in Russia, from where it spread westward to Europe and eastward to Iran and Afghanistan. The estimated total world production for grapes in 2018 was 79,125,982 metric tons up by 6.5 per cent from 74,276,583 tons in 2017. China was the largest producer of grapes, accounting for 16.9 per cent of global production. Italy came second at 10.8 per cent, followed by the United States at 8.7 per cent. In Tamil Nadu level, the productivity in the beginning year was 29.80 million tons and 27.27 million tons in the end year, however during middle of the period the productivity was zigzag movement respectively. The rate of decline in compounded term $(\mathrm{CAGR}=-2.81, \mathrm{t}=-3.75, \mathrm{P}=<0.05)$ is marginally significant at 5 per cent level. The rate of decline production \& productivity in compounded term (CAGR $=-6.18, \mathrm{t}=-2.00, \mathrm{P}=<0.01)$ and $(\mathrm{CAGR}=-3.74, \mathrm{t}=-1.11, \mathrm{P}=0.01)$ are marginally significant at 1 per cent level. It is found that production and productivity are ups and down movement throughout the period.

Key Words: Grape, Production, Productivity, Coefficient of Variation (CV), Compound Growth Rate (CAGR) and Linear Growth Rate (LGR).

\section{A STUDY ON TREND AND GROWTH OF GRAPE IN TAMIL NADU}

\section{Introduction}

Grape cultivation is believed to have originated in Armenia near the Caspian Sea in Russia, from where it spread westward to Europe and eastward to Iran and Afghanistan. In India, Cultivated grapes are believed to have been introduced into the north of India by the Persian invaders in $1300 \mathrm{AD}$, from where they were introduced into the south (Daulatabad in Aurangabad district of Maharashtra) during the historic event of changing the capital from Delhi to Daulatabad by King Mohammed-bin-Tughlak.

Grape (Vitisvinifera) is grown from temperate to warm regions; however, hot and dry climate is ideal. Indian grapes come in varied characteristics namely coloured, white, seeded, unseeded, large and small berries. Indian grapes are successfully grown at and above 250 mean sea levels.

Modern pack house facility with automatic forced air system for precooling is available in all the commercial production areas.Traceability system is maintained for the product tracking. Extensive Residue Monitoring plan for monitoring the pesticide residues in grapes is implemented for consumer safety.

\section{Varieties of Grape}

More than 20 varieties are under cultivation in India. However, only a dozen are commercially grown. They can be grouped under following four categories based on colour and seeds.

\begin{tabular}{|l|l|}
\hline $\begin{array}{l}\text { Coloured } \\
\text { seeded }\end{array}$ & Bangalore Blue, Gulabi (Muscat) \\
\hline $\begin{array}{l}\text { Coloured } \\
\text { seedless }\end{array}$ & Beauty Seedless and Sharad Seedless \\
\hline White seeded & Anab-e-Shahi, Dilkhush (clone of Anab-e-Shahi) \\
\hline White seedless & $\begin{array}{l}\text { Perlette, Pusa Seedless, Thompson Seedless, and its clones Tas-A-Ganesh, } \\
\text { Sonaka and ManikChaman }\end{array}$ \\
\hline
\end{tabular}




\section{Review of Literature}

BhosaleS.S.N.K.Kale, and Y.C.Sale (2016), in their article explained about the area under grapes in Maharashtra has increased by 82.68 per cent and it has increased atthe annual growth rate of 6.68 per cent. The area under grapes has increased in WesternMaharashtra and Marathwada regions. Area under grapes has increased in Nasik district and declined in Sangli and Solapur districts. The highest annual increase in acreages undergrapes was noticed in Osmanabad district and drastically declined in Sangli district which ismajor grape growing district. The production of grapes in Maharashtra has increased by 40.29 per cent over the base year and it has increased at the rate of 6.38 per cent. The increase in production of grapes in Marathwada was more than twice and in Western Maharashtra region marginal decline has noticed. The production of grapes has increased in Osmanabad, district and declined in Sangli district. The productivity of grapes in Maharashtra has declined by 23.20 per cent and it has declined by 0.28 per cent during a period of last ten years. The productivity of grapes has increased in Marathwada region and declined in Western Maharashtra region. The highest productivity was noticed in Osmanabad district and declined in Pune district.

Suresh, Dinesh Kumar R., Dr. Jothi M., (2019), in their article explained about the Agriculture remains a dominating sector for providing employment opportunities to the Indians which records to about 58\%. Also, India stands second largest producer of fruits. However, farming activities are facing many crises due to natural and cost problems causing unviable and unprofitable for farmers who cultivate cash crops. Due to the favorable climatic condition, Tamil Nadu plays as an important state leading in the production of grapes, but in recent times it had witnessed a drastic drop in the grapes cultivation. Therefore, a study about the cost and returns of grapes cultivation is most important for facilitating the farmers and policymakers to bring required changes in production, marketing strategy, and policy changes. To examine the cost and returns of grapes cultivation in the study area the BCR, NPV, IRR and payback period is used. The results indicated favorable economic feasibility of production and a good return for all class of farmers.

\section{Objectives of the study}

This study is undertaken with the following objectives:

1) To study the Area, Production and Productivity of Grape in India level.

2) To study the Area, Production and Productivity of Grape in Tamil Nadu level

\section{Research Methodology}

Source of Data

The present study is primarily based on secondary data. The data were collected fromHorticultural Statistics at a Glance 2018,Horticulture Statistics Division, Department of Agriculture, and Cooperation\& Farmers Welfare.and Websites.

\section{Statistical Techniques}

To analyze the collected data, various statistical techniques like descriptive, time series analysis are used. That is, as the data are of time series in nature, trend and growth both in compounded terms and linear terms are calculated in addition to general descriptive statistics like mean, standard deviation and coefficient of variation. The statistical significance of compound growth and linear trend is ascertained using student t-test.

The procedures for calculating descriptive statistics such as mean, standard deviation, and also for Compounded annualized growth rate (CAGR) and Linear growth rate (CAGR) are given hereunder:

$$
\begin{aligned}
& \text { Mean }(\bar{X}) \\
& \bar{X}=\frac{\sum X_{i}}{n}
\end{aligned}
$$

Where, $X_{i}$ is ratio of year ' $i$ ' and ' $n$ ' is number of years.

\section{Standard Deviation $(\sigma)$}

$$
\sigma=\sqrt{\frac{\sum X_{i}{ }^{2}}{n}-(\bar{X})^{2}}
$$

Where, $X_{i}$ is ratio of year ' $i$ ', ' $n$ ' is number of years and $\bar{X}$ is mean score. 
Coefficient of Variation (CV)

$$
C V=\left(\frac{\sigma}{\bar{X}}\right) x 100
$$

\section{Compounded Annualized Growth Rate}

(CAGR)

Consider the non-linear relationship between a study variable $(\mathrm{Y})$ and time variable $(\mathrm{X})$ as

$$
\mathrm{Y} \quad=\quad \mathrm{a} \quad \mathrm{b}^{\mathrm{X}}
$$

By taking logarithms on both sides, it may be written as

$\log Y=\log a+\log b X$

Or simply say $\mathrm{Y}=\mathrm{A}+\mathrm{BX}$

The least square estimates of $\mathrm{A}$ and $\mathrm{B}$ are given by

$$
\hat{\beta}=\left(\frac{\sum x y-\frac{\left(\sum x\right)\left(\sum y\right)}{n}}{\sum x^{2}-\frac{\left(\sum x\right)^{2}}{n}}\right)
$$

Country - Wise Production of Grapes during the year from 2016 to 2018.

Table No.1

\begin{tabular}{|l|l|c|c|c|}
\hline \multirow{2}{*}{ Rank } & \multirow{2}{*}{ Country/Region } & \multicolumn{3}{|c|}{ Metric Tonnes } \\
\cline { 3 - 5 } & & $\mathbf{2 0 1 8}$ & $\mathbf{2 0 1 7}$ & $\mathbf{2 0 1 6}$ \\
\hline 1 & China & $13,397,012$ & $13,083,000$ & $12,629,000$ \\
\hline 2 & Italy & $8,513,643$ & $7,169,745$ & $8,201,914$ \\
\hline 3 & United States & $6,890,970$ & $6,679,211$ & $7,225,636$ \\
\hline 4 & Spain & $6,673,481$ & $5,387,379$ & $5,950,719$ \\
\hline 5 & France & $6,198,323$ & $5,915,882$ & $6,247,034$ \\
\hline 6 & Turkey & $3,933,000$ & $4,200,000$ & $4,000,000$ \\
\hline 7 & India & $2,920,000$ & $2,922,000$ & $2,590,000$ \\
\hline 8 & Argentina & $2,573,311$ & $1,965,206$ & $1,758,418$ \\
\hline
\end{tabular}

\section{RESULTS AND DISCUSSION} estimate of ' $\mathrm{b}$ ' is given by $\hat{b}=\operatorname{Anti} \log (\hat{B})$ Growth Rate $(\mathrm{CAGR})=\lfloor\hat{b}-1 \mid \times 100$

\section{Linear Growth Rate (LGR)} variable $(\mathrm{Y})$ and time variable $(\mathrm{X})$ as

$$
\mathrm{Y}=\mathrm{a}+\mathrm{b} \mathrm{X}
$$

The Linear Growth Rate $(\hat{b})$ is given by

$$
\hat{b}=\left(\frac{\sum x y-\frac{\left(\sum x\right)\left(\sum y\right)}{n}}{\sum x^{2}-\frac{\left(\sum x\right)^{2}}{n}}\right)
$$
rend are ascertained using Student t-test.

$$
\hat{A}=\bar{Y}-\hat{B} \bar{X}
$$

Where, $\bar{Y}=\frac{\sum y}{n}$ and $\bar{X}=\frac{\sum x}{n}$

Here, $\mathrm{n}$ is number of time periods (years), an

Now, an estimate of Compounded Annualized

Consider a linear relationship between a study

The statistical significance of the growth and 


\begin{tabular}{|l|l|c|c|c|}
\hline \multirow{2}{*}{ Rank } & \multirow{2}{*}{ Country/Region } & \multicolumn{3}{|c|}{ Metric Tonnes } \\
\cline { 3 - 5 } & & $\mathbf{2 0 1 8}$ & $\mathbf{2 0 1 7}$ & $\mathbf{2 0 1 6}$ \\
\hline 9 & Chile & $2,500,000$ & $2,000,000$ & $2,200,000$ \\
\hline 10 & Iran & $2,032,031$ & $1,866,340$ & $2,275,830$ \\
\hline 11 & South Africa & $1,901,736$ & $2,032,582$ & $1,966,291$ \\
\hline 12 & Egypt & $1,759,472$ & $1,703,394$ & $1,691,194$ \\
\hline 13 & Australia & $1,663,557$ & $1,824,431$ & $1,772,911$ \\
\hline 14 & Brazil & $1,591,986$ & $1,912,034$ & 985,074 \\
\hline 15 & Uzbekistan & $1,589,784$ & $1,625,511$ & $1,569,739$ \\
\hline 16 & Germany & $1,403,597$ & $1,014,235$ & $1,225,570$ \\
\hline 17 & Romania & $1,144,305$ & $1,063,340$ & 736,892 \\
\hline
\end{tabular}

Source:https://en.wikipedia.org/wiki/List of countries by grape production

The above table exhibits that list of countries by grape production from the years 2016 to 2018 , based on data from the Food and Agriculture Organization Corporate Statistical Database. The estimated total world production for grapes in 2018 was $79,125,982$ metric tons up by 6.5 per cent from 74,276,583 tons in 2017. China was the largest producer of grapes, accounting for 16.9 per cent of global production. Italy came second at 10.8 per cent, followed by the United States at 8.7 per cent.

Table No.2

All India Area, Production and Productivity of Grapes during the year from 2008-09 to 2017-18.

\begin{tabular}{|l|c|c|c|}
\hline Year & Area in'000Ha & Production in'000MT & Productivity in MT/Ha \\
\hline $2008-09$ & 80.00 & 1878.00 & 23.50 \\
\hline $2009-10$ & 106.40 & 880.70 & 8.30 \\
\hline $2010-11$ & 111.00 & 1235.00 & 11.10 \\
\hline $2011-12$ & 116.00 & 2220.90 & 19.10 \\
\hline $2012-13$ & 117.60 & 2483.10 & 21.10 \\
\hline $2013-14$ & 118.70 & 2585.30 & 21.80 \\
\hline $2014-15$ & 123.00 & 2822.80 & 22.90 \\
\hline $2015-16$ & 121.60 & 2590.00 & 21.30 \\
\hline $2016-17$ & 136.60 & 2921.70 & 21.40 \\
\hline $2017-18$ & 138.90 & 2920.10 & 191.00 \\
\hline Total & 1169.80 & 22537.60 & 19.15 \\
\hline Mean & 116.98 & 2253.76 & 5.16 \\
\hline SD & 16.47 & 711.41 & 26.93 \\
\hline CV & 14.09 & 31.57 & 5.90 \\
\hline & $4.56^{* * *}$ & $10.74 * *$ & $(1.61)$ \\
\hline CAGR & $(5.17)$ & $(3.34)$ & 0.80 \\
\hline & $4.95^{* * *}$ & $196.05^{* * *}$ & $(1.51)$ \\
\hline LGR & $(6.19)$ & $(4.28)$ & \\
\hline
\end{tabular}

t-table value for 8 d.f @10\%=1.85; @5\%=2.30@1\%=3.35.

*Significant at $10 \%$ level; **Significant at $5 \%$ level; ***Significant at $1 \%$ level. 
Source: Horticultural Statistics at a Glance 2018

An attempt has been made to analyze the growth in area, production and productivity of grapes in India for the period from 2008-09 to 2017-18 and the results are given the above table. It is understood from the table that the area and production of grapes with average of 116.98 area in thousand hectare and 2253.76 production in thousand million tons have reached 138.90 area in thousand hectare and 2921.70 in 2017-18 and 2016-17 from 80.00 area in thousand hectare and 1878.00 production in thousand million tons in 2008-09 at significant compound growth rate of 4.56 per cent $(\mathrm{CAGR}=4.56, \mathrm{t}=5.17, \mathrm{P}<=0.01)$ and 10.74 per cent
$(\mathrm{CAGR}=10.74, \mathrm{t}=3.34, \mathrm{P}<0.05)$ with crisscross movements respectively. In absolute value, the rate of growth is 4.95 area in thousand hectare $(\mathrm{LGR}=4.95, \mathrm{t}=$ 6.19, $\mathrm{P}<=0.01)$ and 196.05 ( $\mathrm{LGR}=196.05, \mathrm{t}=4.28, \mathrm{P}$ $<=0.01)$ on an average every year for area and production respectively. In the case of productivity there has been a ups and down movement from opening year to end year with significant growth rate of 5.90 per cent when compounded annually and 0.80 in million tons on an average every year when measured in absolute value respectively.

Table No.3

Area, Production and Productivity of Grapes in Tamil Nadu during the year from 2008-09 to 2017-18.

\begin{tabular}{|l|c|c|c|}
\hline Year & Area (in'000 Ha) & Production ( in '000MT) & Productivity (Ha/MT) \\
\hline $2008-09$ & 3.10 & 91.00 & 29.80 \\
\hline $2009-10$ & 2.60 & 44.10 & 16.80 \\
\hline $2010-11$ & 2.70 & 53.00 & 19.30 \\
\hline $2011-12$ & 2.90 & 55.10 & 19.00 \\
\hline $2012-13$ & 2.70 & 43.40 & 16.20 \\
\hline $2013-14$ & 2.80 & 47.70 & 16.80 \\
\hline $2014-15$ & 2.31 & 32.63 & 14.10 \\
\hline $2015-16$ & 2.44 & 34.10 & 13.97 \\
\hline $2016-17$ & 2.49 & 29.02 & 11.67 \\
\hline $2017-18$ & 2.16 & 58.93 & 27.27 \\
\hline Total & 26.20 & 488.98 & 184.91 \\
\hline Mean & 2.62 & 48.90 & 18.49 \\
\hline SD & 0.28 & 17.83 & 5.80 \\
\hline CV & 10.73 & 36.47 & 31.383 \\
\hline CAGR & $-2.81^{*}$ & $-6.18^{* * *}$ & $(-1.11)$ \\
\hline LGR & $(-3.75)$ & $(-2.00)$ & -0.60 \\
& -0.07 & $-3.34^{* *}$ & $(-0.94)$ \\
\hline
\end{tabular}

t-table value for 8 d.f @10\%=1.85; @5\%=2.30@1\%=3.35.

$*$ Significant at $10 \%$ level; $* *$ Significant at $5 \%$ level; ***Significant at $1 \%$ level.

Source: Compiled from Horticulture Statistics Division, Department of Agriculture, Coopn\& Farmers Welfare.

Despite a significant increase in area in thousand hectare and production in thousand million tons with the average of 2.62 times and production with an average of 48.90 times has declined marginally during the period. This shows that a grape has gradually reduced during the overall period. But from year to year figures, there have been a zigzag movement in both area and productions. This scenario is very similar in respect of productivity also. The productivity in the beginning year was 29.80 million tons and 27.27 million tons in the end year, however during middle of the period the productivity was zigzag movement respectively. The rate of decline 
in compounded term $(\mathrm{CAGR}=-2.81, \mathrm{t}=-3.75, \mathrm{P}=<$ 0.05 ) is marginally significant at 5 per cent level. The rate of decline production \& productivity in compounded term $(\mathrm{CAGR}=-6.18, \mathrm{t}=-2.00, \mathrm{P}=<0.01)$ and $(\mathrm{CAGR}$
$=-3.74, \mathrm{t}=-1.11, \mathrm{P}=0.01)$ are marginally significant at 1 per cent level. It is found that production and productivity are ups and down movement throughout the period.

Table No.4

District-wise Area, Production and Productivity of Grapes in Tamil Nadu during the year 2017-18

\begin{tabular}{|l|l|c|c|c|}
\hline S.No & Districts & $\begin{array}{l}\text { Area } \\
\text { (in Ha) }\end{array}$ & $\begin{array}{l}\text { Production } \\
\text { (in Tonnes) }\end{array}$ & $\begin{array}{l}\text { Productivity } \\
\text { (inTonnes/Ha) }\end{array}$ \\
\hline 1 & Coimbatore & 77.00 & 918.00 & 11.92 \\
\hline 2 & Dharmapuri & 4.00 & 111.00 & 27.75 \\
\hline 3 & Dindigul & 199.00 & 2675.00 & 13.44 \\
\hline 4 & Erode & 6.00 & 166.00 & 27.67 \\
\hline 5 & Krishnagiri & 16.00 & 443.00 & 27.69 \\
\hline 6 & Madurai & 3.00 & 83.00 & 27.67 \\
\hline 7 & Namakkal & 3.00 & 55.00 & 18.33 \\
\hline 8 & Salem & 1.00 & 28.00 & 28.00 \\
\hline 9 & Sivagangai & 3.00 & 55.00 & 38.33 \\
\hline 10 & Theni & 1685.00 & 50681.00 & 28.00 \\
\hline 11 & Tiruppur & 1.00 & 28.00 & 28.00 \\
\hline 12 & Tiruchirappalli & 1.00 & 28.00 & 27.67 \\
\hline 13 & Tirunelveli & 3.00 & 83.00 & 27.67 \\
\hline 14 & Vellore & 9.00 & 249.00 & 55603.00 \\
\hline & State Total & 2011.00 & 5.65 & \\
\hline
\end{tabular}

Source:http://tnhorticulture.tn.gov.in/horti/tnhorticulture/application/pdf/201718_Area, Production (Final).pdf

The above table reveals that the area of grapes in Dindigul District (199 Area in Ha) is also found to be second to Theni District (1685.00 Area in Ha).Theni District was the largest producer of grapes, accounting for 50681.00 in tons of Tamil Nadu production. Dindigul District came second at 2675.00 tons, followed by the Krishnagiri District at 443.00 tons. As far as concern in productivity level Salem, Tiruppur and Tiruchirappalli Districts are stood at first places, on the other hand Dharmapuri District stood at second place.

\section{Conclusion}

Major grape growing states are Maharashtra, Karnataka, Telangana, Andhra Pradesh, Tamil Nadu, and the North-Western region covering Punjab, Haryana, Western Uttar Pradesh, Rajasthan and Madhya Pradesh. Maharashtra ranks first in terms of production accounting for more than 81.22 per cent of total production and highest productivity in the country. Grape is one of the important fruit covering an area of 123 thousand hectares occupying 2.01 per cent of the total area. The country is also a major exporter of fresh Grapes to the world. The country has exporter 1, 93,690.55 MT of Grapes to the world for the worth of Rs.2, 176.88crores/ 298.05 USD Millions during the year 2019-20.Major Export Destinations (201920): Netherland, Russia, U K, Bangladesh Prand Germany.

\section{References:}

- Agarwal, S. G. (1981), Components of Expenditure and Total Cost involved in Producing Duck and Chicken for Meat. The Indian Veterinary Journal, 10-15.

- Dr. D.Paul Dhinakaran, "Exports and Imports Stagnation in India During Covid-19- A 
Review” GIS Business (ISSN: 1430-3663 Vol15-Issue-4-April-2020).

- Babu, H. M., Reddy, B. V., \&Umesh, K. B. (2016). Impact of National Food Security Mission on Production and Incomes of Paddy Farmers: An Economic Study in Hassan District, Karnataka. Indian Journal of Agricultural Economics, 463-478.

- Balamurugan, S. (2009),A Study of Cost and Returns of Vanilla Cultivation in India. Madurai: Ph.D. thesis submitted to Madurai Kamaraj University.

- Bhosale, S.S., (February 2004), Present Status and Export Potentials of Grapes in India, Agricultural Situation in India, Vol.LX, No.11.

- Bhosale S.S.N.K.Kale, and Y.C.Sale, Trends in Area, Production and Productivity of Grapes in Maharashtra, International Journal of Advanced Multidisciplinary

Research,DOI:10.22192/ijamr Volume 3, Issue 10 -2016. Pp 21-29.ISSN: 2393-8870

- Carlos E. Carpio, C. D. (2008), Estimated Costs and Investment Analysis of Producing and
Harvesting Muscadine Grapes in the Southeastern United States. Hort Technology, 308-317.

- Dr. D.Paul Dhinakaran, "Community Relations Of Tamilnadu State Transport Corporation Ltd 'International Journal Of Research And Analytical Reviews ( E ISSN 2348-1269, print ISSN 2349-5138) Special Issue March 2019.

- K.Venkat Reddy, P. K. (2017), Economic Analysis of Coconut in West Godavari District of Andhra Pradesh. IOSR Journal of Business and Management, 68-72.

- Krishnamoorthy. (1999), Resource Use of Efficiency in Seedless Grape Vineyards.

- Suresh, Dinesh Kumar R., Dr. Jothi M., Cost and Returns of Grapes Cultivation in Tamil $\mathrm{Nadu}$,International Journal of Management StudiesVol.-VI, Issue -1(6), January 2019, [99] ISSN(Print) 2249-0302 ISSN (Online)22312528 http://www.researchersworld.com/ijms/ DOI : 10.18843/ijms/v6i1(6)/12 , DOI URL :http://dx.doi.org/10.18843/ijms/v6i1(6)/12 